NBER WORKING PAPER SERIES

\title{
LIBERALIZATION IN CHINA'S KEY SERVICE SECTORS FOLLOWING WTO ACCESSION: \\ SOME SCENARIOS AND ISSUES OF MEASUREMENT
}

\author{
John Whalley \\ Working Paper 10143 \\ http://www.nber.org/papers/w10143

\begin{abstract}
NATIONAL BUREAU OF ECONOMIC RESEARCH
1050 Massachusetts Avenue

Cambridge, MA 02138
\end{abstract} \\ December 2003
}

\begin{abstract}
I am grateful to my discussant John McHale, participants in the Industry Canada Conference on Services Industries and Knowledge-Based Economy; Winnipeg, Oct 16-18 2003, and to David Wang of Unicentury, Shanghai, and Justin Lin of CEPR, Peking University for extremely helpful discussions and comments. Shunming Zhang (Tsinghua and UWO) and Terry Sicular (UWO) have also provided helpful comments. Eric $\mathrm{Ng}$ has provided helpful research assistance and comments. The views expressed herein are those of the authors and not necessarily those of the National Bureau of Economic Research.
\end{abstract}

(C2003 by John Whalley. All rights reserved. Short sections of text, not to exceed two paragraphs, may be quoted without explicit permission provided that full credit, including $(\subset$ notice, is given to the source. 
Liberalization in China's Key Sevrice Sectors Following WTO Accession:

Some Scenarios and Issues of Measurement

John Whalley

NBER Working Paper No. 10143

December 2003

JEL No. F0

\begin{abstract}
This paper documents and assesses the significance of the policy changes in China that WTO accession implies in 3 key service categories (banking, insurance, and telecoms), asking whether it is likely they will really be fully implemented in their entirety as undertaken at signature in 2002. While it would seem that China will have extraordinarily open markets for these services by 2007 (and for banking, perhaps in the world), the starting point for implementing these policy changes seems so highly restricted that doubts have been raised about the feasibility of implementing such changes over such a short time even if threats of eventual retaliation from WTO partners speeds things along. WTO members are monitoring the implementation of China's WTO commitments, and following dispute settlement might retaliate in the future were these agreed changes not to be implemented. I discuss what scenarios this liberalization might follow, and ask whether these commitments can really be implemented as undertaken.

John Whalley

Department of Economics

University of Western Ontario

London, ON N6A 5C2

Canada

and NBER

jwhalley@uwo.ca
\end{abstract}


Taken at face value, the commitments that China has taken on in the services area as part of their WTO accession process are simultaneously extraordinarily deep and wide ranging. Breathtaking has been an adjective frequently used to describe them. Over a 5 year period from 2002 to 2007 China will seemingly fully open all of its markets to full international competition from foreign service providers in a series of key areas; distribution, telecommunications, financial services, professional business and computer services, motion pictures, environmental services, accounting, law, architecture, construction, and travel and tourism. All barriers to entry in the form of discriminatory licenses to operate will be removed and all conduct barriers in the form of differential regulation for domestic and foreign entries will be removed. The possible implications of the implementation of these commitments over the next five years provides the focus of this paper.

I first both document and assess the significance of the policy changes in China that WTO accession implies in 3 key service categories (banking, insurance, and telecoms), asking whether it is likely they will really be fully implemented in their entirety as undertaken at signature in 2002. While it would seem that China will have extraordinarily open markets for these services by 2007 (and for banking, perhaps in the world), the starting point for implementing these policy changes seems so highly restricted that doubts have been raised about the feasibility of implementing such changes over such a short time even if threats of eventual retaliation from WTO partners speeds things along. WTO members are monitoring the implementation of China's WTO commitments, and following dispute settlement might retaliate in the future were these agreed changes not to be implemented. I discuss what scenarios this liberalization might follow, and ask whether these commitments can really be implemented as undertaken. Other issues I touch on are how large the potential market for these services might 
be, and how large foreign penetration into the Chinese market for service providers in these areas could realistically be.

To evaluate their possible impacts I discuss the limited literature that exists on trade liberalization in key service areas which recognize their individual characteristics, and contrast it to the larger literature which treats all services as analytically equivalent to goods and discusses services liberalization in a conventional trade policy framework. ${ }^{2}$ I then outline a theoretical framework in general for both discussion and measurement of impacts of liberalization in these areas and discuss its applicability to China. Most analytical literature on trade policy still discusses barriers to services trade as if tariff equivalents were involved, while the barriers at issue are quite dissimilar to tariffs since there is no customs clearance for services. For instance, China is planning to use progressive expansion of allowable foreign ownership and geographical coverage of licenses as the liberalization instrument. Granting of licenses is discrete and ad valorem tariff equivalent modelling of their removal can be misleading. How should we think about negotiated liberalization in these areas as it applies to the Chinese case, and how does it compare to using an alternative continuous protective instrument like a tariff for which rates can be varied? And what of geographical limitations on licenses which may be varied gradually (more and more cities, for instance); how does such continuous liberalization behave relative to conventional tariff based liberalization?

Finally, I discuss what might be involved quantitatively with these liberalizations. Are the gains likely to be as large as some have claimed ${ }^{3}$ and who might benefit? How might such liberalization affect overall economic performance in China and what are the scenarios? How

\footnotetext{
${ }^{2}$ See Copeland (2002) and Whalley (2003).

${ }^{3}$ In a recent modelling exercise using the GTAP database and modelling framework Dee and Hanslow (2000) project gains of $18 \%$ of GDP for China from banking reforms alone. This reflects a large initial spread in borrowing and lending rates which is assumed to be greatly narrowed by liberalization. See also the quantification of Chinese WTO accession in Walmsley and Hertel (2001).
} 
large a share of world service markets could be involved, and what of new competition and new opportunities abroad? Will activity in liberalized areas in China continue to be via domesticforeign joint ventures as at present, or will that change? And what might be the implications for liberalization elsewhere in other countries? 


\section{Trade Liberalization in Key Services Categories}

Prior to discussing more concretely the impacts of China's WTO accession in the key services areas of banking, insurance, and telecoms, it may be useful to first discuss the broader literature on services liberalization in general. Most of this is descriptive, relatively little is analytical, and most of it does not distinguish between different service categories on a characteristics basis. $^{4}$

The presumption behind most discussion of country interest in potential services trade liberalization is that countries gain from more open services trade in ways which are similar to trade liberalization in goods. This reflects the idea that countries have differing comparative advantage in the production of both goods and services, and that more open trade will allow comparative advantage to be more fully exploited in all countries. Put simply, the thinking is that propositions regarding the gains from freer trade apply equally to both goods and services. There are, however, many complications with this line of argument even though it is instinctively where most academic economists seem to finish up in their thinking.

Services constitute a majority of activity for most OECD economies (as measured by employment, and by value added originating), and a smaller but still large portion of activity for developing countries. So-called "core" services can best be thought of (see Melvin 1989) as relating to intermediation through time (banking, insurance) or space (telecoms, transportation, retailing, wholesaling), with a wide range of diverse additional service items making up the balance of what most people refer to as services (tourism, consulting services, government services, utilities). This diverse range of activities is typically treated in both quantitative and theoretical work as a single homogenous entity, frequently labeled as services for convenience, when its heterogeneity seems to clearly call for a different treatment for each.

\footnotetext{
${ }^{4}$ Much of this is reviewed in Whalley (2003).
} 
Whether goods and services differ in some important way, raises the issue of whether they need to be approached differently in evaluating the impacts of liberalization in each. Much, if not most, of the existing literature treats services as analytically similar to goods. The approach is to define a single product, commonly called producer services, which is an input into production and against which trade protection operates through a tariff like instrument. Liberalization is then a reduction in or elimination of the tariff equivalent. Not surprisingly, results from models using this approach are similar to those analyzing trade liberalization in goods. In numerical models of goods liberalization small positive gains accrue to most countries if no factor mobility effects are captured (see Whalley (2003)).

In reality since services facilitate transactions they typically provide the economic function of intermediation either through time or space. This idea is reflective of a heterogeneous group of activities spanning banking, insurance, transportation, telecoms, consulting services, retail and wholesale trade, and several others. Explicitly modelled in this way, this can produce different implications for trade liberalization from conventional goods analysis.

Ryan (1990, 1992) shows, for instance, that when banking is explicitly modelled as intermediation services that themselves do not directly provide utility, but instead facilitate intermediation between borrowers and lenders, liberalization of trade in banking services can reduce GDP, and even welfare. Chia and Whalley (1997) have produced a numerical example of welfare worsening trade liberalization in banking services based on this approach. The results from such examples reflect the use of specific analytical structures, parameter values and functional forms and are hence not general results. These results do, however, suggest a further weakening in the general presumption that gains will result in countries where liberalization of service trade occurs. Bhattarai and Whalley (1998) provide a related analysis of the implications 
of liberalization in network services (effectively telecoms) where the same theme emerges that recognition of the special features of individual services changes the analysis of the impacts of services liberalization. They show how with network externalities present the division of the gains from liberalization in service networks differs from that of the case of goods. More generally, there is no reason to think that trade liberalization in goods and services are independent of each other: liberalization in services when tariffs still apply to goods can easily be welfare worsening, for instance.

Even if trade in goods and services are treated as analytically similar then how countries benefit from services trade liberalization is subject to all of the nuances set out in the literature on trade policy for goods liberalization. While most academic economists seemingly believe at the end of the day that there are benefits for all countries from freer trade in goods, over the years they have nevertheless devoted a considerable portion of their intellectual energy to producing arguments as to why the contrary may be true. These include arguments for an optimal tariff (terms of trade improvement from protection), for infant industry protection, for tariffs which transfer rents (rent shifting), and tariffs that offset other domestic distortions.

There are also qualifying arguments about protection of trade in goods that relate in one way or another primarily to developing countries and these also come into play in discussing the impacts of liberalization in services. One example would be that in a Lewis trade model with traditional practices in agriculture (average rather than marginal product pricing of labour) protection of traded goods sectors is called for to pull labour into import competing modern sectors; in a Harris Todaro model with an urban sector specific downward rigid real wage and unemployment an import subsidy can be beneficial. 
Another difference from goods liberalization is that to achieve meaningful trade liberalization in services modifications of factor mobility restrictions may be required which may not be needed for goods liberalization. This is recognized in Modes 3 and 4 of GATS which effectively relate to capital (FDI) mobility and labour (service provider) mobility. With restricted or segmented factor markets (and especially labour markets), large effects can come if services liberalization becomes an indirect mechanism for liberalizing domestic factor markets. This is a central issue for countries who have long pushed for liberalization of immigration controls in OECD countries, since global services liberalization may be a vehicle for them to achieve this end (see Hamilton and Whalley (1984), Winters (2002) and Winters, Walmsley, Wang and Grunberg (2002)).

A further issue in discussing trade liberalization in services and its impacts on individual countries is that the types and forms of liberalization need to be fully and carefully specified. For goods trade most discussion of liberalization focuses on tariffs (and less so) on other instruments since barriers to the flow of goods typically arise as customs and other physical restraints on trade are administered at national borders.

Barriers to service provision may operate through entry barriers to local markets (rights to establish, or to provide services), rules on conduct (regulation), on the number and size of competitors in a market (competition rules), and in other ways. As a result more barriers come into play with services trade than with goods. They are more complex, and their effects more numerous. Market structure, conduct, and performance are all key and all need to be evaluated when discussing quantitative impacts of liberalization of services trade on individual countries.

Also, since services generally have no tangible form and hence cannot be physically restrained at the border, foreign service providers typically need to have to have entry to the 
national market either for the service itself or for themselves or their agent. The entity that provides the service, (or the service providers themselves) may be restricted in terms of their mobility, and it is here that many restraints on services trade effectively operate. Within the services trade community, and in the policy literature in general, there is an understanding that the outcomes of services liberalization will depend heavily on the regulatory environment agreed on.

All these considerations and more need to be borne in mind when approaching services trade liberalization in China linked to WTO accession, and the specific characteristics of the Chinese economy also need to be taken into account. These include extensive state owned enterprise activity, losses by many (or most) state owned enterprises, extensive non-performing loans, powerful provincial governments and interprovincial competition, limited property rights and seemingly weak legal enforcement and other characteristics. Analyzing the impacts of China's WTO accession terms not only faces all the difficulties and limitations on the mechanical application of literature on liberalization posed above because services are involved; or must also confront the many formidable challenges that Western style neo-classical economics faces in making sense of economic phenomena observed in contemporary China. 


\section{China's Banking, Insurance, and Telecoms Sectors and the Implications of China's WTO Accession}

\section{Overview}

The changes which are scheduled for China's key service sectors as part of WTO accession are by any stretch of the imagination extremely far reaching. In the banking area, through participation in the WTO Financial Services Agreement under the framework of the GATS, China has committed herself to full market access for foreign banks within five years. The current regime is restrictive of foreign banks. Foreign banks are not allowed to conduct local currency (Remnimbi) business with foreign businesses or individuals. Geographical restrictions apply to the establishment of foreign banks. These forms of restriction will go, and China will

allow internal branching and provide national treatment for all newly allowed activities by foreign entities. Local currency business will be allowed with Chinese enterprises two years after WTO accession, and with Chinese individuals five years after.

In the insurance area, few foreign insurers operate in the Chinese market, and prior to WTO accession China reserved the right (seemingly on arbitrary grounds) to limit operations by city and to terminate existing rights. Under its WTO commitments, China agrees to limit licenses only on prudential grounds with no limits on the number of licenses issued. China will progressively eliminate geographical restrictions on licenses within three years, and will also allow internal brokerage.

In telecoms, China's Ministry of Information Industry (MII) has agreed to new rules for basic and value added services in telecoms. The commitment is to allow for more foreign ownership and less geographical restriction of licenses. This will limit the ability of dominant local carriers to keep rates high and depress demand for telecommunications services and electronic commerce. China has also agreed in its accession protocol to undergo a special Trade 
Policy Review Mechanism (TRM) exercise in the WTO, under which the WTO's 16 subsidiary bodies and committees will review the country's progress on implementation each year for the next eight years. By any stretch of the imagination, if fully implemented all these commitments amount to major new market opening in China in terms of access for foreign suppliers for core intermediation services.

\section{Banking $^{5}$}

Foreign financial institutions are being permitted to provide foreign currency services in China immediately following Chinese accession to the WTO and without any restrictions as to clients or location. The Remnimbi (or foreign exchange certificate), the local currency, will for now remain inconvertible. Local currency business will then be opened up in step by step fashion over 5 years (until 2007). China will also open foreign banking business in local currency in twenty cities in five groups within four years of accession. Within 5 years of accession, foreign financial institutions will be allowed to provide retail banking services everywhere in local currency, and to all Chinese clients. Foreign institutions will also be allowed to provide intermediary and advisor services freely, including deposit services, financial lending services, merger and acquisition advice, and securities investment advice.

A number of foreign or joint venture banks have already received licenses as part of the implementation of China's WTO commitments. These include the Bank of East Asia, Citibank, Hang Seng, HSBC, and Standard Chartered. Rights to offer Remnimbi lending to foreign companies and individuals have been extended beyond regional pilot programmes. When

\footnotetext{
${ }^{5}$ See also the detailed discussion of China's banking sector and the implications of WTO accession in Bhattasali (2002).
} 
China's WTO commitments are fully implemented the entire Chinese banking sector will then be fully open to foreign competition.

No other economy of any significant size anywhere in the world, as far as I am aware, currently comes close to this degree of openness in its regulatory structure for financial institutions. Exceptions are smaller countries such as tax havens like the Cayman Islands or the Bahamas. And the initial starting point for these reforms is so far away from the planned termination point (in part because the role of the Chinese banking sector in the past differs sharply from that of an OECD economy), that there have inevitably been doubts expressed as to the ability of China to fully implement these commitments.

The extensive changes that the Chinese banking system will have to undergo to implement the provisions of WTO accession in large part reflect the history of China since 1949 as a centrally directed economy with unique political order. Prior to the economic reforms of the 1990's China had a planned economy with development of heavy industry as the priority for its economic development. ${ }^{6}$ The financial system was a central and integral part of this planning structure, much as in the former Soviet Union (see Holtzman (1951)). Regular financial market activities were banned, and the People's Bank of China (PBOC) was the single financial institution. It acted both as a central bank and as a provider of banking services via deposits and loans, but loans were made almost exclusively to state owned enterprises.

Today, while the Chinese banking system exhibits a wider range of financial institutions with the PBOC now acting solely as a central bank the function of the banking system is still largely as before. State owned enterprises remain the largest borrower from the banking system, ${ }^{7}$ and four large state owned banks conduct most of this business. Relatively few individuals have

\footnotetext{
${ }^{6}$ See Lin, Cai, and $\mathrm{Li}$ (1998) for a discussion of this evolution.

${ }^{7}$ See the description in Broadman (2001).
} 
bank accounts. Personal assets (houses, autos) when acquired are usually paid for in full. Financing for these usually reflects informal credit (loans from family or friends).

State owned enterprises typically consistently lose money, and state owned banks have major difficulties with non-performing loans. Official estimates put these as high as $25 \%$ of loans outstanding, but unofficial estimates are as high as $50-60 \%$ of loans outstanding (see Zhang (1999), Yuan (2000), and Bonin and Huang (2001). The Central Bank continually recapitalizes the state banks who in turn lend money to loss making state owned enterprises. It is still believed in China that this structure can prevail as long as growth continues at high levels, and indeed it has prevailed for the last 15 or so years, but if growth significantly slows then trouble may follow for the banking system in China and with it the industrial sector and the real side of the economy. ${ }^{8}$

At the top tier of the Chinese Banking System (the largest part of the system) are four large state banks; China Industry and Commerce Bank, China Agriculture Bank, Bank of China, and China Construction Bank. These account for the majority of non-performing loans made to state owned enterprises. They are under no explicit mandate to lend heavily to state entities, but do so on the grounds such loans are safe (i.e. they are state to state loans), even though recipient enterprises lose money and cannot directly service their debt. The expectation is that the state (via the banking system) will bail out loss making enterprises and the loans involved will eventually be repaid.

The second tier involves locally owned banks, such as the Shanghai Bank, and the Shenzhen Development Bank. These operate in similar ways to the state owned banks, but are under different political control (typically provincial or citywide). The third tier consists of three major policy based regional shareholder commercial banks, the Construction Agricultural

\footnotetext{
${ }^{8}$ See the repeated expression of concerns on this score by Western economists such as Lardy (1998).
} 
Development Bank, the Import/Export Bank, and the Bank of China (foreign currency bank). A fourth tier involves mixed individual enterprise owned banks. Ownership here includes state owned enterprises, local enterprises, and local governments.

Few of these banks issue securities which are traded on stock markets. Currently there are only four banks for whom trading takes place and this is in class A shares (which are only allowed to be held by Chinese residents).

Direct participation by foreign financial institutions in this banking system is extremely limited, but it is beginning. According to Lin (2001), by early 2000 foreign banks and financial institutions had already established 191 representative offices and subsidiaries in 23 city locations in China with total assets of $\$ 36$ billion. ${ }^{9}$ Many foreign banks have also recently been allowed to upgrade their representative offices to branches and to conduct local currency business in Pudong and Shenzhen. Even more recently, foreign financial institutions have acquired minority share ownership in smaller mixed ownership banks. For instance, Newbridge Financial have acquired a 15\% interest in Shenzhen Development Bank, and Citicorp have taken a 5\% interest in Pudong Development Bank.

But to complete the implementation of China's WTO accession commitments by 2007 more major changes will have to occur, which if enacted would seemingly substantially change the structure of the Chinese economy (also see Lin (2000)). For instance, foreign entry into banking services could provide strong competition for local banks who are not only believed to be inefficient but also saddled with large non-performing loans. Some believe that the local banking industry could be greatly impacted by such changes and hence such change cannot easily be accommodated. Others argue that an incentive will remain for China to keep the Remnimbi inconvertible so that foreign banks will have little initial access to Remnimbi deposits

\footnotetext{
${ }^{9}$ Bhattasali (2002) reports the same data.
} 
and hence will be unable to make local currency loans. Another argument sometimes heard is that only the local Chinese banks fully understand how business is done in China, and hence local banks will keep most of their market share, especially in more remote rural areas.

But as subsidies to state owned entities are also to be terminated as part of the WTO accession process, loan activities based on an expectation they will continue to be paid them must also seemingly change. China's WTO commitments as they affect banking services thus need to be seen in their totality, both as they relate directly to the banking sector and also to other real side sectors in the economy. Given the scope of all China's commitments the banking system seemingly must change from a structure which seemingly defacto continually recapitalizes loss making state owned enterprises closer to a more conventional commercial banking system offering genuine intermediation. For this to happen the whole real side of the economy must seemingly also undergo substantial change along with the banking sector, which is what WTO accession implicitly foresees and OECD country negotiators in the WTO assume that Chinese negotiators were aware of even if this was not formally acknowledged by them.

\section{Insurance}

The present situation in insurance in China differs considerably from that in banking, and implementation of WTO commitments in this area will likely be easier to achieve. Most insurance activity in China is business related. There is relatively little personal life or house insurance, although the car insurance market is growing rapidly with the growth of autos.

The tiering of insurance companies differs from that characterizing the banking sector since there is no insurance analogue to the central bank. First come wholly state owned insurance companies who are non profit, and account for around $70 \%$ of Chinese insurance business; the 
largest being Peoples Insurance and Life. Next comes joint share insurance companies owned by state owned enterprises of which the largest is Pacific. Then come joint venture insurance companies of various forms, followed by wholly foreign owned companies directly offering insurance services, largely to Chinese companies. The latter are typically branches of foreign insurance companies.

Unlike banking, foreign entry to China's insurance market is already allowed for through licensing, and though building from a small base an entry point has already been established for foreign insurance providers. Licenses for life insurance operations have been granted on a city basis to American International and Sun Life. Indeed, in insurance the main barriers to foreign activity seem not to be policy related but are more market driven. ${ }^{10}$ The Chinese market is seen by foreigners as complicated because of (for foreign companies) unusual organizational forms, legal and other arrangements, differing business customs, and the need for Chinese language skills to conduct business. Since foreign insurance companies seem to find it hard to do business in China entry by them into the market has been difficult. As a result, foreigners do not always accept licenses to operate, even when applied for and offered. According to Chinese insurance providers, many opportunities for joint ventures have not been taken up even though there are no formal barriers to prevent them from being pursued.

Thus, in insurance foreign entry to the Chinese market is both already possible and allowed, but foreigners seemingly do not take up new entry opportunities quickly. As a result, the terms of WTO accession in insurance seemingly pose fewer problems for China than in banking since the market seems formally open to foreigners, even if appearing defacto closed. As

\footnotetext{
${ }^{10}$ This may be more the perception on the Chinese side than that of OECD trade negotiators, but is as communicated to me in China on a recent visit.
} 
a result WTO accession in insurance may pose fewer adjustment pressures for China than in banking.

\section{Telecoms $^{11}$}

In telecoms, the present situation is that seven operators are currently licensed in China reflecting a regulatory structure inherited from prior reforms in 1999. The most significant entity in the sector is China Telecom (CT) originally part of the Ministry of Posts and Telecommunications and established as a separate entity in 2000. CT controls $99 \%$ of China's main fixed line phone capacity. Next comes China Unicom, the major mobile phone operator, established in 1994. Then come a series of enterprises with regulatory approval to operate in various telecom markets. These include a satellite operator ChinaSat, a broadband IP network developer China Netcom, as well as China Telecommunications Broadcast Satellite Corporation, Jitong, and China Railways Communications.

The current situation is that defacto two large state owned providers (China Unicom, and Telecom China) dominate the market. There is both rate and entry regulation. This structure applies both for basic (hardwire and mobile) telecom services and for peripheral add-on services. Rates are set at above international levels and profits of these utilities are a significant revenue source for both national and provincial governments.

The main commitments stemming from China's WTO accession involve partial the removal of limits on market access (especially the right to establish) and the removal of limits on national treatment. Foreign investment will be allowed in the sector, but initially with geographical restrictions and with limits placed on the ownership level. Geographical restrictions are to be removed and the foreign ownership limit is to be raised to $49 \%$ for most services in two

\footnotetext{
${ }^{11}$ See the extensive discussion of the telecoms situation in Pangestu and Mrongowius (2002).
} 
years for so-called value added services, five years for mobile telephones, and six years for international services.

As part of WTO accession China has also signed the WTO Telecommunications Agreement which requires free entry to this market for foreign service providers by 2007. This would place China on a par with practice in the larger OECD economies where in recent years foreign providers frequently and freely access foreign markets and large rate reductions have occurred.

Fresh issues arise in telecoms with liberalization to follow on from implementation of WTO accession which differs from banking and insurance. One involves the revenue implications of foreign telecoms entry for national and provincial governments since both benefit from the revenue source of participating in regulated utilities either directly or indirectly under their management. Another is that barriers to new entrants occur represented by prior joint participation in existing network structures and the costs to consumers in switching when new entry occurs. The analytical basis for assessing the welfare consequences of telecoms liberalization in light of these features seems little studied generally, even before special features of the Chinese situation are factored in.

\section{Scenarios for Implementation of WTO Commitments}

As already noted above, China's commitments in key service areas seem so extensive that they inevitably lead to some questions of both the feasibility and likelihood of full implementation. The commitments demanded of China for WTO accession were agreed to as part of China's latest drive towards modernization. Once in place they become WTO commitments subject to dispute settlement and enforcement through retaliation. Whether China 
can retain enough autonomy to keep the unique economic structure it now has and whether political opposition will ensue and in some way limit their full implementation is the issue.

On the infeasibility side, the concerns usually focus on the possible disappearance of much of domestic industry in these service categories under WTO implementation ${ }^{12}$ and the potential unacceptability of this were it to happen (and the political impact of the resulting labour market dislocation) as well as the perceived strategic need for domestic service industries (as argued by Brazil for their own banking sector in the WTO, for instance). Believers in such liberalization would stress the benefits to China from the gains from trade, but such benefits even if achieved will likely not remove opposition to change. A conjecture that has been advanced is that Chinese negotiations either were not really fully aware of what they were committing to or if so aware believed there was some form of escape still available though other unconstrained regulation (perhaps new licenses of some form). Those taking this line often argue that all these pressures will likely eventually force some kind of defacto renegotiation of accession terms or a slowing of implementation, even though other country WTO members would likely take the line that renegotiation is impossible since the commitments involved are all set out in firm contractual form.

On the feasibility side, the arguments are that services liberalization in China to be implemented as part of WTO commitments fits into a wider developmental strategy of SOE containment and achievement of efficiency gains and resource allocation improvements. The claim is that domestic service industries can compete in an internationally freer environment. One possible supporting mechanism sometimes suggested involves other policy elements in the equation which will shield Chinese industry from adjustment (such as an inconvertible Remnimbi in the case of banking). Since implicit threats to pursue WTO dispute settlement and

\footnotetext{
${ }^{12}$ The likelihood of this in the banking sector is discussed by Bhattasali (2002).
} 
retaliation (if necessary) characterize the position of US and other OECD country WTO negotiations (in public at least) the argument is that China will have no choice but to implement their commitments in these key service areas.

A further possible issue is whether some form of defacto renegotiation of Chinese accession terms in services could be part of an agreed package of global trade policy changes following on from the 2004 termination of the Multi Fibre Arrangements (MFA). This is based on the assumption that global free trade in textiles and apparel (a dominant Chinese interest) will not follow the termination of the MFA, and that some new negotiated globally managed trade regime in textiles and apparel will follow. To achieve this, OECD negotiators may have to pay a price elsewhere and part of this could possibly be to agree to slow down or change the implementation process for China's WTO accession. If this were to occur (which is highly conjectural at this point) the form both of a new textile order and a slowing down of Chinese WTO commitments could follow any of several paths.

Many question marks thus remain both over China's objectives in negotiating WTO services liberalization, her ability to implement it and the resolve of foreigners to push it through. In what follows I will assume full implementation and proceed to an evaluation of potential impacts on this basis, but these questions about what might really happen as the process unfolds all have to be kept in mind. 


\section{Analytic Structures For Evaluating Chinese Services WTO Commitments}

The key elements of service liberalization implied by the WTO commitments made by China are in areas where intermediation services dominate, namely banking, insurance, and telecoms. The services at issue primarily involve intermediation of various types through time (as in banking), space (telecoms) or across risk categories (insurance); transportation is largely excluded. To evaluate the possible impacts of liberalization in these areas in China some analytical structure is needed. It should be noted that at present analytical literature on liberalization in key service sectors for any economy (and not just China) is limited and in many ways not particularly helpful.

A first observation to make is that services liberalization when tariffs apply to trade in goods need not be welfare improving even in simple trade models if goods and services interact in some way. Also the analytical basis for the desirability of free trade in these service categories is more fragile than many realize since existing literature on services liberalization generally does not take into account the characteristics of particular service items, and so a general discussion of the desirability of free trade in all services as if they were all analytically similar may be misdirected.

As Ryan (1990, 1992) point out intermediation type services do not themselves typically directly enter preferences. In the case of banking, for instance, it is only commodities purchased with the financing obtained that directly affects any individual's welfare. Individuals with identical consumption of other goods get the same utility from, say, a car whether it is debt financed or whether it is purchased with cash. The use of intermediation services to arrange the financing of a car does not, in and of itself, directly provide utility. Financial intermediation services bring together borrowers and lenders and this facilitates intertemporal trade, but 
intermediation requires real resources. The two theorems of welfare economics will typically not hold in such a world since real resources are used to facilitate trade. It is also not obvious that, from a global efficiency point of view, free international trade in banking services will be preferred to autarky. ${ }^{13}$

The effects on resource allocation and welfare of trade liberalization in banking services can differ relative from those obtained from more conventional no transactions costs models. The outcome is ambiguous because gains from trade coexist with increased resource use in intermediation activities which directly generate no welfare. The outcome depends on the configuration of initial endowments, consumption patterns and the volumes of desired transactions, with resource use in transaction costs depending on the pattern of transactions between agents.

Chia and Whalley (1997) use a transactions cost framework to construct numerical examples which show how free international trade in banking services can be either globally welfare-worsening or welfare-improving. Their examples use a model with CES preferences, and two countries (Home $(\mathrm{H})$ and Foreign $(\mathrm{F})$ and two time-dated consumption goods $\left(c_{1}\right.$ and $\left.\left.c_{2}\right)\right)$. Intermediation cost margins are assumed for the two countries $\mathrm{H}$ and $\mathrm{F}$ respectively. They follow the same approach as in the applied general equilibrium literature of calibration of a model to an initial microconsistent equilibrium data set, followed by equilibrium solution for a counterfactual equilibrium. In their examples the initial equilibrium involves autarky in banking services, while the counterfactual equilibria each involve free international trade in banking services.

\footnotetext{
${ }^{13}$ General equilibrium models incorporating transactions costs were developed some years ago by Foley and others [Foley (1970)]. They differ from the standard Arrow-Debreu model which underlies conventional Heckscher-Ohlin trade theory and standard analysis of the gains from trade in that in the presence of transactions costs the effective resource endowment of the economy (i.e. net of resource use in transactions) is affected by the volume of trade.
} 
To construct an example which shows welfare-worsening liberalization for all individuals in all countries, they fix the consumption patterns in each region in an assumed microconsistent equilibrium data set which they use in calibration, and then they vary the endowment patterns and elasticities in their model parameterization until they find a counterfactual equilibrium with the desired property that services liberalization is welfare worsening. Each manipulation they make changes the volume of trade effects under liberalization and they are able to relatively quickly produce a welfare-worsening example. In one example they report all consumers in both counties are made worse off by liberalization in banking services by the same proportion of income through accompanying transfers between consumers.

Ryan (1990) provides a theoretical explanation for these results. He shows that it is possible for freer trade to cause total world output to fall (as resources required by services rise) while welfare as a whole rises. The paradox arises because intermediation services do not enter the utility function directly, even though they enter via the mix of goods consumed. Thus, when free trade permits access to more efficient intermediation services, world output of final goods may fall (or as is the case in this paper more resources paid to servicers) but each agent consumes a better mix of goods than was available in autarky. If agents consume a better mix of goods under free trade, they are also consuming more intermediation services. If services are not considered as part of welfare, then simply calculating post-free-trade aggregate bundles using pre-trade prices can seemingly lead to the result that free trade is welfare worsening.

Ryan further shows that the result depends upon the elasticity of intertemporal substitution, since this affects the demand for intermediation services as barriers to their trade are removed. He shows that for CES utility functions, a necessary (though not sufficient) condition for world output to fall is that the elasticity of substitution is strictly greater than one. The 
numerical results of Chia and Whalley are consistent with the theoretical explanation offered by Ryan and both taken together suggest some caution in accepting the proposition that liberalization of trade in intermediation type services will necessarily lead to country welfare gains.

In more recent work $\mathrm{Ng}$ and Whalley (2003) explore a further characteristic of Chinese liberalization in services as it might apply to goods trade, namely the progressive geographical expansion in coverage of licenses to include more and more of the country over time. They highlight two central features of Chinese services liberalization that are present in all the three areas of banking, insurance, and telecoms; namely the use of geographical expansion in licenses and the progressive raising of allowed ownership levels for foreign investors as liberalization vehicles. They discuss how in the absence of tariffs for protective purposes (typically not possible for intermediation services) available protective measures such as a license are discrete instruments. Foreign firms either have a license to operate or they do not, and no continuity exists in the use of the instrument.

$\mathrm{Ng}$ and Whalley evaluate the implications of progressive geographical expansion of licenses and argue that this provides a continuous (and negotiable) instrument in the case where licensing is the only feasible instrument of protection. They consider an economy with, in the case of trade in goods, administratively feasible internal borders which are shiftable and for which zones can be constructed. In one zone trade takes place at world prices, in the other it takes place behind the protective effect of a tariff.

They then consider parameterizations for these two economies for which there is observationally equivalent trade liberalization. They analyze liberalizations across the two with identical trade flow impacts, but which yield sharply differing welfare impacts. One 
liberalization is in a traditional goods trade model of a single integrated market economy with a tariff. The other is an economy with a shiftable border for a protected zone as above. In the first, liberalization of goods trade occurs by reducing the tariff. In the other, liberalization of goods trade occurs by moving the location of the free trade zone leaving the tariff rate unchanged. They consider cases of both pure exchange economies and economies with production.

In the numerical examples they provide, even with similar preferences and production structures welfare gains from liberalization which yield equivalent trade impacts are larger by factors of up to 4 for zone liberalization. These results suggest that conventional trade policy formulations of services liberalization might perform poorly as predictors of welfare impacts of liberalization of the type characterizing key Chinese service sectors upon WTO accession.

Liberalization in service networks is discussed in a recent piece by Bhattarai and Whalley (forthcoming). They model economies with networks linking consumers who both exchange messages and trade goods. They first consider disjoint networks in which consumers have interdependent preferences in which utility increases in the number of message contacts with other consumers, but consider networks to be initially country specific. Liberalization across countries in telecoms is the joining together of two disjoint networks. In this case, if a small and large country integrate, then consumers in the small country receive large per capita benefits since they receive large increases in call frequency due to access to a larger message market. The reverse is true for the larger country. The net effect is that gains from liberalization are typically of roughly equal absolute size across countries independently of relative country size. This differs from the case of trade in goods where small countries typically gain proportionately more.

Thus when asked what analytical literature relevant for assessing the impacts of Chinese services liberalization suggests, while limited clearly it does point to the conclusion that a 
mechanical application of insights from conventional trade policy literature for goods market liberalization to Chinese WTO accession in services may well be misleading. Relatively little literature on the welfare impacts of services liberalization that explicitly incorporates their economic characteristics seems to exist. The implications of existing work seem to be firstly that gains to China need not occur, and secondly that conventional tariff based analyses of impacts (as in Dee and Hanslow (2000)) may be misleading, and that country division of gains from services liberalization may differ from what is typical for trade in goods. 


\section{Quantifying the Effects of Services Liberalization in China}

Quantifying the impacts of services liberalization and especially of banking liberalization in China is extremely difficult, and this is so for a number of reasons. Not only is there little analytically based literature currently available on banking liberalization for any country, several special features of the Chinese environment and situation need to be taken into account. These include the role of banking sectors as a mechanism for recapitalizing state owned enterprises, the degree of non-performing loans and the need for real side reforms to accompany banking liberalization. At this point information on the situation with non-performing loans in the banking system is only available a fragmentary basis and is unreliable (see Lu, Thanyavelu and $\mathrm{Hu}$ (2001), and Bonin and Huang (2002)).

As a result, there are strongly competing schools of thought as to what might happen upon full implementation of WTO accession terms but these are not necessarily reflective of evaluation using analytical structures. Some see inefficient Chinese banks ${ }^{14}$ as being swept aside through WTO commitment implementation by competitive and more efficient foreign banks unencumbered by bad debts. Others see domestic banks with superior knowledge of local markets continuing to thrive in a more open market environment. Those of this persuasion emphasize the knowledge of the local market conditions which local banks experience, the complex legal environment and differing customs of practice, and the role of an inconvertible Remnimbi in protecting local banks. Bonin and Huang (2002) evaluate both of these two scenarios for the outcome of liberalization, without being able to easily differentiate between them.

Major difficulties in evaluating data on barriers to service trade are a further problem, not only for China but more broadly. Much of available data on service trade barriers is frequency

\footnotetext{
${ }^{14}$ See the discussion in $\mathrm{Xu}$ and $\mathrm{Lu}(2001)$ and Cull and $\mathrm{Xu}(2000)$.
} 
data, and follows earlier work by Hoekman (1995), and subsequently refined by Dee et al (2000) and others. ${ }^{15}$ These estimates are aimed at yielding tariff like equivalents of barriers to flows of banking services, but are unsatisfactory in practice since they do not necessarily represent the binding restrictions on trade, such as licenses. Using barrier estimates of this form some rudimentary quantification of the gains or losses to China from banking liberalization have been made, such as by Dee and Hanslow (2000), which show large effects; in the region of $18 \%$ of GDP for banking and telecom reforms combined. They use the GTAP modeling framework and database and evaluate trade and welfare effects of barriers removed in a traditional model structure similar to that used to analyze liberalization in goods except that factor mobility (capital flows) enter their analysis.

Dee and Hanslow report that of US $\$ 130$ billion of gains arising globally from global services trade liberalization under a Doha Round WTO scenario about $\$ 100$ billion would accrue from liberalization in China alone. Global services trade liberalization in their model results seemingly imply that the effects involving access for foreigners to the Chinese banking market over the next few years will dominate all other aspects of global services trade liberalization. Whether such gains will occur in practice remains to be seen.

Dee and Hanslow seemingly offer no explanation for the result in their text other than to say that large barriers to service flows are involved in the Chinese case. Their barrier estimates are indeed large; a little over $250 \%$ as tax equivalent barriers to foreign affiliate capital accessing the Chinese market. These seemingly reflect the strong assumption that trade barriers to all services in China can be represented as tax equivalents (mark ups of price over cost) and this applies equally to banking, telecoms and other services. They use a Kalirajan et al (2001) study which measures the effects of foreign access restrictions on the net interest margins of banks,

\footnotetext{
${ }^{15}$ See the discussion in Whalley (2003).
} 
which they suggest is a direct measure of bank mark up of price over cost. They also use Warren's (2001) measure of the effects of trade restrictions on the quantity of telecommunications services delivered, converting these to price impacts using estimates of price elasticities of demand for telecommunication services. Dee and Hanslow's results thus seemingly follow directly from their large barrier estimates for China when used in a conventional trade model.

One can also query whether these barrier measures are satisfactory. In China, four large state owned banks provide most of the financing for the large state owned enterprise sector, suffer from major non-performing loans and make losses. Rate spreads at the margin are high, but foreign entrants to market lending under similar conditions would also require large spreads. Smaller private banks lending only to the commercial sector have smaller spreads. At the margin, therefore to assume a $250 \%$ barrier to foreign capital try to enter Chinese service markets may make little sense.

An alternative way to estimate the potential effects of services liberalization in China is to look at the outcome under present regulation and then to assess this relative to a free market equilibrium in a structure which explicitly models the service characteristics involved. In banking, for instance, one can argue that the net effect of the present structure is to effectively exclude the private sector from access to credit, while credit is over extended to state owned enterprises. The net effect is too much capital in the SOE sector and too little capital in the private sector. This situation is reflected in Figure 1, where the free market outcome is what is implied by liberalization and the hatched area represents the area of potential gain from liberalization. 
Under an assumption that the SOE sector is four times the size of the private sector in China's non agricultural economy, that the differential rate of return on capital is $25 \%$ across the two sectors, and that the production function exponent parameter on the variable capital input in both sectors is 0.5 , the gain to China from financial market liberalization is of the order $25 \%$ of GDP. Such estimates are discussed in $\mathrm{Ng}$ (2003), where a range of sensitivity calculations for such estimates is also reported. While such estimates are conjectural at best, they do suggest large potential benefits to China from banking liberalization under these scenarios.

\section{Figure 1}

\section{Gains from liberalization affecting the allocation of capital between private $(\mathrm{P})$ and state owned enterprise sectors (SOE) in China}

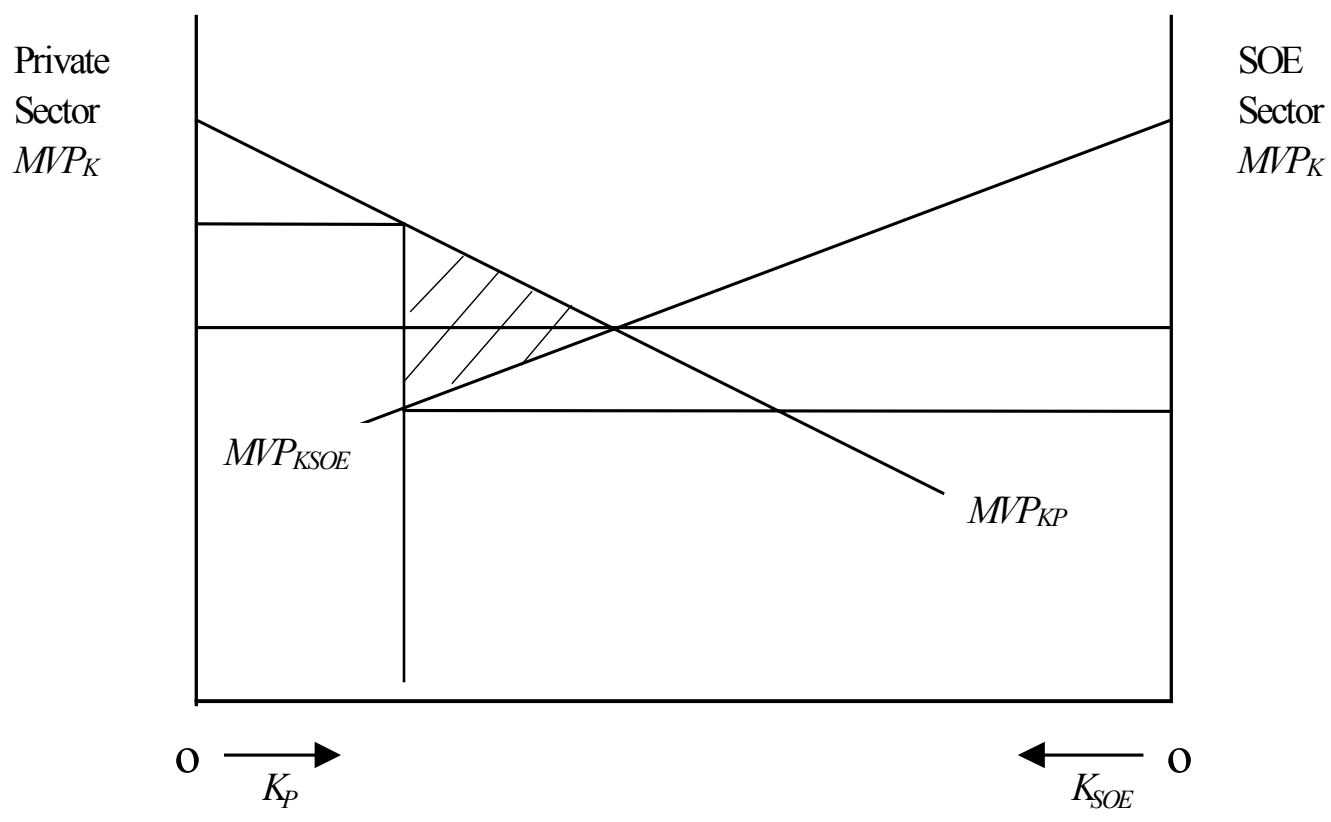

If, however, liberalization of banking were to occur with no change in the soft budget constraint arrangement for the SOE sector and their loses continued to be covered by the state 
and the banking sector continued to be used to recapitalize loss making state owned enterprises, then liberalization would only lead to further expansion in the SOE sector and an efficiency loss for the Chinese economy. Under this view of the world, current restrictions on banking are needed to limit the loan activity of SOE's who believe that government bail outs of all losses will occur should they borrow more funds. Thus while seemingly large potential gains might ensue for China from WTO financial services (and also potentially in insurance and telecoms) liberalization, the reference point used in evaluation makes a major difference. It also makes a large difference how the real side of the economy is modelled in such calculations.

Other ways of viewing the interaction between China's banks and the state owned enterprises also affect the way in which welfare gains or losses might result from liberalization. If one views Chinese state owned enterprises as effectively captured jointly by management and workers, and managers use the enterprise to extract loans from the state for enterprises they form while workers shrink, then a joint outcome which is Pareto inferior results. Loans to the SOE sector then already go indirectly to the private sector (via management of SOE's and their private sector activity), and the net effect of liberalization in banking may largely be to reduce transactions costs. This would be reflected in reduced consumption of restaurant meals in China and other transacting activities. If this were accompanied by reduced labour shirking, this could be the biggest effect of banking liberalization in China. Quantifying the effects of liberalization accompanying the implementation of WTO commitments is thus difficult for China's key service sectors. It seems likely that large effects might ensue, but the reference point for their evaluation makes them difficult to both quantify and sign. 


\section{Concluding Remarks}

That China's commitments as part of the terms of their accession to WTO in the areas of banking, insurance, and telecoms are wide ranging is beyond doubt. Whether China will be able to fully implement these commitments over the implementation period from 2002 to 2007 and with what effect are the issues which followed are discussed in this paper. Few changes in the global economy over the next few years match the scale of changes implied in Chinese service arrangements. Literature is ambiguous as to whether effects will be beneficial or harmful for China, large or small, or who may be affected and in which way.

This paper highlights the many gaps in both our knowledge and approach to an evaluation of the likely impacts of one of the most important sets of changes which the global economy of the next five years will experience. Models of services liberalization in general are unsatisfactory in accounting for many economic phenomena. In China data is sparse. Different reference points for evaluation offer different perspectives as to sign, let alone size of impact.

The current implications of what research there is suggests that large positive gains will occur both for China and the global economy. But at the same time large changes in both China's financial structure and real side economy have to take place. Much of China's intermediation service activity (banking for instance) underpins the current structure of the economy as still state owned enterprise dominated. State owned banks are effectively a vehicle for recapitalizing loss making state owned enterprises, rather than for intermediating private sector borrowers and lenders as in OECD economies. The scope of change which WTO accession seeming mandates in China is vast, and poorly understood. Whether this is feasible in the five years from 20022007 only time will tell. The more negative scenario is that implementation is infeasible and China (and the world) are on a collision course to WTO sanctioned retaliation after 2007. 


\section{$\underline{\text { References }}$}

Bhattarai, Keshab and John Whalley (1998), "The Division and Size of Gains from Liberalization of Services Networks", National Bureau of Economic Research Working Paper: 6712, August 1998; forthcoming in Review of International Economics.

Bhattasali, D. (2002), “Accelerating Financial Market Restructuring in China”, World Bank mimeo.

Bonin, J.P. and Y. Huang (2002), "Foreign Entry into Chinese Banking: Does WTO Membership Threaten Domestic Banks?", The World Economy, vol. 25, August,pp.1077-1094.

Broadman, H.E. (2001), "The Business(es) of the Chinese State”, The World Economy, vol. 24, July 2001, pp. 849-876.

Chia, Ngee Choon and J. Whalley (1997), “A Numerical Example Showing Globally WelfareWorsening Liberalization of International Trade in Banking Services", Journal of Policy Modelling, April 1997; 19(2): 119-27.

Copeland, Brian (2002), "Benefits and costs of trade and investment liberalization in services: Implications from trade theory" in Curtis, J.M. and D.C. Ciuriak, eds. Trade Policy Research 2002. Department of Foreign Affairs and International Trade, Canada 2002.

Cull, Robert and Lixin Colin Xu (2000), "Bureaucrats, State Banks, and the Efficiency of Credit Allocation: The Experience of Chinese State-owned Enterprises", Journal of Comparative Economics, vol. 28, pp. 1-31.

Dee, P. and K. Hanslow (2000), "Multilateral Liberalization of Services Trade", Productivity Commission Staff Research Paper, Ausinfo, Canberra.

Foley, Duncan (1970), “Equilibrium with Costly Marketing”, Journal of Economic Theory. Sept. 1970; 2(3): 276-91.

Hamilton, B. and J. Whalley (1984), "Efficiency and Distributional Implications of Global Restrictions on Labour Mobility: Calculations and Policy Implications", Journal of Development Economics, 14(1-2) January-February 1984, pp. 61-75.

Hoekman, B. (1995), "Assessing the General Agreement on Trade in Services", in W. Martin and L.A. Winters (eds), The Uruguay Round and the Developing Economies, Discussion Paper No. 307, World Bank, Washington DC, pp. 327-64.

Holtzman, F. (1951), Banking in the Soviet Union, Columbia University Press.

Kalirajan, K., G. McGuire, D. Nguyen-Hong and M. Schuele (2001), "The price impact of restrictions on banking services", in Findlay C. and T. Warren, eds, Impediments to Trade in Services: Measurement and Policy Implications, New York: Routledge. 
Lardy, N.R. (1998), “China and the Asia Financial Contagion”, Foreign Affairs, July/August.

Lardy, N.R. (1998), China's Unfinished Economic Revolution, Brookings Institution, Washington DC.

Lin, J.Y. (2001), "WTO Accession and Financial Reform in China”, The Cato Journal, vol. 21, No. 1, Spring/Summer, pp. 13-19.

Lin, J.Y. (2000), "What is the Director of China's Financial Reform?", in Went Cai and Feng Lu (eds.) China Economic Transition and Economic Policy, Beijing, Peking University Press, pp. 296-301.

Lin, J.Y., Fang Cai, and Zhou Li (1998), The China Miracle: Development Strategy and Economic Reform, Hong Kong, Chinese University Press.

Lu, D., S.M. Thanyavelu, and Q. Hu (2001), "Biased Leading and Non Performing Loans in China’s Banking Sector”, (mimeographed, National University of Singapore).

Melvin, James R. (1989), “Trade in Producer Services: A Heckscher-Ohlin Approach”, Journal of Political Economy, October 1989, 97(5): 1180-96.

Ng, E. (2003), “Assessing the Impacts of Banking Liberalization in China”, mimeo, University of Western Ontario.

Ng, E. and J. Whalley (2003), “Geographical Expansion as Trade Liberalization”, mimeo, UWO.

Pangestu, M. and D. Mrongowius, (2002), "Telecommunications in China: Facing the Challenges of WTO Accession", World Bank, mimeo.

Ryan, Cillian. (1990), "Trade Liberalization and Financial Services", The World Economy, Sept 1990, Vol. 13, No.3, pp. 349-366.

Ryan, C. (1992), "The Integration of Financial Services and Economic Welfare” In A.L. Winters ed, Trade flows and trade policy after 1992. Cambridge; New York, Melbourne: Cambridge University Press, 1992; 92-118.

Walmsley, T.L. and T.W. Hertel (2001), "China's Accession to the WTO: Timing is Everything”, The World Economy, vol. 28, August, pp. 1019-1050.

Whalley, J. (2003), "Assessing the Benefits to Developing Countries of Liberalization in Services Trade", Draft Report prepared for OECD Trade Directorate.

Winters, L. Alan (2002), "The Economic Implications of Liberalizing Mode 4 Trade", Joint WTO-World Bank Symposium on 'The Movement of Natural Persons (Mode 4) under the GATS’, WTO, Geneva, 11-12 April, 2002. 
Winters, A., T. Walmsley, Z.H. Wang and R. Grunberg (2002), "Negotiating the Liberalization of the Temporary Movement of Natural Persons", Discussion paper 87, University of Sussex, October 2002.

$\mathrm{Xu}$, Guoping and Lu Lei (2001), "Incomplete contracts and moral hazard: China's financial reform 1990's", Journal of Financial Research (Tin Rong Yan Jiu) vol. 2, pp. 28-41.

Yuan, Gangming (2000), “An Empirical Analysis of Non-performing Loans in China's SUEs”, Economic Research Journal (Tan Ji Yan Jiu), vol. 5, pp. 12-20.

Zhang, Jie (1999), "Non performing Loans of State Owned Banks in Transition Economy", Journal of Financial Research, May. 